\title{
The Impact Of The European Economic Integration On The Uk's Foreign Direct Investment
}

\author{
Mihaela Simionescu \\ Institute for Economic Forecasting of the Romanian Academy \\ Centre for Migration Studies in Prague Business School
}

\begin{abstract}
The main aim of this paper is to assess the impact of European economic integration on the UK's foreign direct investment. The objective is achieved by using two types of methods: difference-in-difference estimator for a comparison with other countries outside the EU and mixed-effects regression to evaluate the role of economic welfare of origin countries and their EU membership. Even if on long-run the UK attracted more FDI compared to OECD countries outside the EU in the period 1970-2017, the EU membership did not bring a high increase in the UK's FDI. On the other hand, the GDP per capita and exports in the origin countries seem to be more important in deciding to invest in the UK rather than the EU membership of these countries.
\end{abstract}

Key-words: European economic integration, FDI, difference-in-difference estimator, mixedeffects model

JEL Classification: C51, C53, F21 


\section{Introduction}

Two groups of economists were defined in relation to their opinion on the possible economic effects of Brexit. Most economists anticipate that Brexit will negatively influence trade, foreign investment in the UK and labour migration. The second group consists of few experts, who have a positive view of the post-Brexit period (Economists for Brexit, 2016; Capital Economics, 2016). However, the magnitude of Brexit's impact on the British economy and its subsequent effects on economic activities remain controversial. Brexit's possible negative effects on the UK economy can be best anticipated by comparison with the positive effects of the UK's integration in the EU.

Considering the debate on Brexit and European economic integration, the main aim of this paper is to assess the effects of European economic integration on bilateral FDI and on FDI that were attracted by the UK. The approach is based on two methods: the method based on differencein-difference estimator to compare UK with OECD countries that are outside the EU and Poisson and linear generalized models on panel data to explain FDI based on economic situation in the origin countries. The results indicated that the economic welfare in the origin countries is more important than the EU integration when the foreign investors decide to start or to develop a business in the UK.

After this short introduction, the paper makes a presentation of literature review in the field. The next section comes up with the empirical applications. Last part concludes.

\section{Literature review}

Some empirical researches have assessed the impact of European economic integration on FDI attracted by the UK lately, the importance of this assessment increasing in recent years in the context of Brexit. According to estimates provided by Pain (1997), the Single Market Program has positively influenced the FDI inflows attracted by the UK in the period 1981-1992 at industry level. Pain and Lansbury (1997) have shown that the Single European Market has stimulated the attraction of FDI to the UK and Germany in the period 1981-1992, as well as the redirection of the FDI made by the UK into the US. In the case of the UK, using the synthetic control method, Campos and Coricelli (2015) demonstrated the positive impact of EU membership on FDI, measuring an increase in bilateral FDI flows by $25 \%$ to $30 \%$ in the period 1986-2015. Using other econometric methods (Poisson and Heckman models, least squares method), the authors showed an increase in bilateral FDI in average by almost 28\%. Moreover, Straathof et al. (2008) noted that UK FDI stocks increased by $28 \%$ when investors were EU member states in 2016 compared to the previous year and only by $14 \%$ when investors did not come from the EU countries.

Using a microeconomic approach, Benito et al. (2003) suggested that, unlike Norway, which is not a member of the EU, Denmark and Finland attracted more FDI due to their European economic integration.

\section{9}


As EU accession has stimulated the attraction of FDI, we can consider that the European economic integration itself is a determinant of FDI, although the literature does not explicitly list this factor among the determinants of FDI. However, European economic integration is not enough to build a strategy to attract FDI. The EU Member States should continue to pursue the quality of the workforce and its ability to incorporate process or product innovations (Narula, 2009). The emphasis should not be on cheap labor, but on human capital quality (Radulescu and Jianu, 2011).

The explanation for attracting more FDI in the process of preparation for EU integration and for the effective EU integration can also be related to economic geography. Geographical proximity also involves increases in FDI, a determinant of FDI specified in the literature (Beavan and Estrin, 2000). The economic integration is related to the adoption of a common law designed to ensure institutional stability. Transparent and low-level corruption institutions that have emerged as a result of EU integration have led to more FDI (Tintin, 2013). In the case of the Central and Eastern European countries that joined the EU, besides geographical proximity and common European law, there were other factors that contributed to the attraction of FDI in these countries: reduced labor costs, market size and rating credit.

In the case of the EU Member States, existing theories in the literature on FDI can be expanded by adding to each of the FDI theories the European economic integration as determinant. Kilic et al. (2014) identified the determinants of FDI in relation to three sets of theories that directly explain FDI in relation to their determinants: microeconomic theories, macroeconomic theories, and development theories that combine macro and micro-level theories.

Microeconomic theories express the perspective of multinational enterprises (MNEs) trying to explain why these companies choose FDI rather than licensing or exporting (oligopolistic market theory, eclectic theory, company-specific theory, internalization theory). Macroeconomic theories consider FDI to be a type of capital flow between different economies to explain the causes and determinants of FDI (exchange rate theory, gravity approach, macroeconomic dynamics theory, economic geography, capital market theory, institutional analysis). Theories of development consist of: product life cycle theory, Japanese FDI theories, and Dunning's Five-Step Theory.

As many studies have shown that European economic integration has been a major determinant of FDI attracted by the UK, we might expect to lower FDI inflows after Brexit. Ebell and Warren (2016) explain the increase in FDI attributed by the UK due to the EU integration through the free movement of capital, goods and services, but also through labor mobility. The benefits of FDI in the UK are related to the transfer of advanced technologies to domestic firms, increased productivity and performance of firms, higher salaries provided to employees by foreign firms. Alfaro et al. (2004) have shown that FDI contributes to the economic growth of the UK, mainly due to the development of the financial sector. Thus, in the period 1994-2003, GDP grew on average by $2.25 \%$ in the UK only due to attracted FDI inflows and EU membership, as Pain and Young (2004) showed using a macro -model with fiscal and endogenous monetary policies. Under these circumstances, the decline in FDI after Brexit can also bring drops in output and employment, slower technical progress, and lower labor productivity. In the context of the Brexit negotiations, the UK registered a fall of \$ 181 billion in FDI in 2017 compared to 2016, a drop of nearly $92.4 \%$ that means the lowest level since 2005 . 
Most scenarios of FDI change after Brexit are made on the long and medium term, with few studies evaluating the impact of Brexit on the short-term on FDI (Baker et al., 2016 a; Baker et al., 2016 b; HM Treasury, 2016; Kokotovic and Kurecic, 2017). It is difficult to assess the shortterm impact because of the uncertainty of the post-Brexit policies, which is hard to include in the econometric model, and because of exchange rate fluctuations.

Although there is a prediction for possible falls in FDI in the UK after Brexit, amid the great uncertainty that characterizes the dynamic and unstable international environment, some authors do not provide concrete forecasts of FDI decline. For example, Driffield and Karoglou (2016) suggested, based on a Markov-style vector-autoregressive model, a negative impact of Brexit on FDI attracted by the United Kingdom. Dhingra et al. (2018), but also Bailey et al. (2017) show that the magnitude of the fall in FDI depends on the policies that will be implemented by the UK after Brexit. In this context, several policy recommendations for Brexit are envisaged: flexible policies that promote trade with countries where the costs are lower and employee protection is lower. Based on a pseudo-Poisson model of maximum veracity applied to 34 OECD countries in the period 1985-2012, Welfens and Baier (2018) showed that after Brexit, the UK will face three shocks that will affect the FDI inflows:

- The exit from the Single European Market will bring about a fall in FDI inflows; - If the capital stock of foreign firms established in the UK will increase significantly in 2019, some of the outflows in the EU will be diminished by increasing the ratio of FDI stock to capital stock that may reflect Froot-Stein's depreciation effect of pound in the period 2016-2018; - If the UK government opts for economic recovery through more FDI attracted, a reduction in corporate taxes can generate strong effects, but may also stimulate corporate tax cuts.

However, there are many recent surveys interested in anticipating the effects of Brexit on FDI attracted by the UK and on economic growth in the country, suggesting various scenarios for the decline in FDI (Mansfield, 2014, Campos and Coricelli, 2015; Irwin, 2015, Barret et al. , 2015; Ebell and Warren, 2016; Dhingra et al., 2016; Featherstone, 2016; Kierzenkowski and others; 2016; Simionescu, 2017; Jafari and Britz, 2017; Blackaby, 2018).

Campos and Coricelli (2015) predicted a fall in FDI inflows in the first year after Brexit by $12 \%, 28 \%$ and $25 \%$, respectively, depending on the model used to predict (OLS regression, Heckman model and model Poisson). Authors' scenarios are close to the PWC forecast (2016), which suggests a possible reduction of $25 \%$ in FDI by 2020. Dhingra et al. (2016) predicts a decline of about $28 \%$ by 2020 and the forecast of Bruno et al. (2016) show a smaller decrease of $22 \%$. Dhingra et al. (2016) used some gravity models to explain bilateral FDI flows between the UK and 34 OECD countries in the period 1985-2013. By 2020, McGrattan and Waddle (2017) expect a fall in FDI inflows in the UK of $0.5 \%$ to $1 \%$ and in outflows to the EU by $1.5 \%$ to $2 \%$. Long-term scenarios have been built by Ebell and Warren (2016) and anticipated a drop in FDI in the UK by 2030 by $12 \%$ to $28 \%$, while economic growth may range between $1.5 \%$ and $3 \%$. However, Kekic (2017) considers that Brexit's negative effect on FDI will only exist in the short term, while in the long run FDI will grow again. A survey made by the Confederation of the British Industry in 2013 predicts that $35 \%$ of foreign firms will cut their investment after Brexit (Confederation of British Industry, 2013). 
In addition to the scenarios on bilateral FDI or FDI attracted by the UK, there are also studies covering only FDI made by certain EU or non-EU countries in the UK. For example, knowing that Ireland is one of the UK's leading economic partners, Barrett et al. (2015), and Wordin (2018) anticipated fewer FDI made by Ireland in the UK, which could negatively affect Ireland's economic growth and the Irish energy market, but can contribute to the development of the financial sector in Ireland after Purdue and Huang (2015). The decline in Ireland's FDI into the UK, as well as the decline in Ireland's GDP after Brexit, are also anticipated by Bergin et al. (2017) based on scenarios using a core structural model (COre Structural MOdel-COSMO) for the Irish economy. There are various potential agreements between the EU and the UK after Brexit, but in all cases Brexit's negative influence on FDI and output in Ireland is expected. If different agreements are considered (European Economic Area, Sweden model and World Trade Organization model), the drops in Ireland's FDI made in the United Kingdom are 9.7\%, $17 \%$ and $23.7 \%$.

The volume of FDI made by Switzerland and Norway, two non-EU states, in the UK, could fall by $17.1 \%$ and $9.7 \%$ respectively, according to Ebell and Warren (2016). Similar projections were provided by the Treasury (a 10\% decrease in FDI by Norway and between $15 \%$ and $20 \%$ in the case of FDI from Switzerland).

Although most studies anticipate a negative effect of Brexit on UK FDI, the Open Europe model greatly mitigates this effect. However, expectations based on the Open Europe model are not plausible, as the model is built on the fixed exchange rate assumption and does not include short-term transit costs (Harvey and Hubbard, 2016).

\section{Empirical analysis}

We start from the following regression model:

$$
Y_{i t}=\alpha+\beta_{1} E_{-} \text {integration }_{i t}+\beta_{2} \text { time }_{i t}+\beta_{3} E_{-} U_{\text {integration }} \text { time }_{i t}+\varepsilon_{i t}
$$

Y- dependent variable represented by FDI net inflows (percent of GDP)

time, intervention - dummy variables

The variable time takes the value 0 before 1973 and the value 1 from 1973, the year when the UK joined the EU.

The variable $E U \_$integration takes the value 1 for the country that is EU Member State and 0 for the rest. 
$\mathrm{i}, \mathrm{t}$ - indexes for countries and years

The data series for the variable cover the period 1970-2017. Data for net FDI inflows (as percent of GDP) is provided by the World Bank database. The cross-sections are represented by the UK and non-EU OECD countries.

Two groups of countries are considered: United Kingdom and non-EU OECD countries (Canada, Mexico, Chile, Australia, USA, Turkey, New Zealand, Japan, Israel, Norway, Iceland, Korea). The difference between the UK and the rest of the non-EU OECD countries in terms of net FDI inflows as percent of GDP after the UK entrance into the EU is not statistically significant as

shown

in

Table

1.

Table 1. Impact of the UK integration in the EU on net FDI compared to non-EU OECD countries (1970-2017)

\begin{tabular}{|l|l|l|l|}
\hline Variable & \multicolumn{1}{|c|}{ Coefficient } & t-stat & $\mathbf{P}>|\mathbf{t}|$ \\
\hline time & 1.087 & 3.24 & 0.001 \\
\hline intervention & 0.060 & 0.02 & 0.980 \\
\hline time $x$ intervention & 2.846 & 2.14 & 0.035 \\
\hline Constanta & 0.756 & 0.63 & 0.530 \\
\hline
\end{tabular}

Source: author's calculations

The difference in net FDI inflows between the UK and the rest of OECD countries that are not in the EU is not statistically significant. If the UK had not entered the EU, FDI inflows would have increased by almost 1.09 percentage points in the period 1970-2017. The expected change in average FDI before the UK's entry into the EU was different between the two groups of countries. After the UK's entry into the EU, this country attracted by 2.8 percentage points more net FDI than non-EU OECD countries. Thus, over time, EU membership of the UK was significant, but the FDI growth was not very high.

Poisson models with mixed effects and models with fixed and random effects were built to explain the bilateral FDI and those attracted by the UK in the period between 2001-2016 The sample of countries considered in the analysis is represented by 25 countries: Austria, Belgium, Cyprus, Denmark, Finland, France, Germany, Greece, Ireland, Italy, Luxembourg, Netherlands, Poland, Portugal, Romania, Spain, Sweden, Isle of Man, Norway, Switzerland, Canada, US, Australia, Japan and New Zealand.

Table 2 suggests a positive impact of exports and GDP per capita on FDI, suggesting the British preference for attracting foreign investors from developed countries. Moreover, developed countries prefer making investment in other developed countries rather than in more than in 
developing countries in Eastern Europe. Although the impact of EU membership is positive, it is not statistically significant, suggesting that the degree of economic development of the partner countries is a priority for the UK and not simply EU membership.

Table 2. Poisson regression model with mixed effects to explain bilateral FDI between the UK and other countries (2001-2017)

\begin{tabular}{|l|l|l|l|l|}
\hline Variable & Coefficient & $\begin{array}{l}\text { Robust } \\
\text { standard error }\end{array}$ & $\mathbf{z}$ & $\mathbf{P}>\mathbf{z} \mid$ \\
\hline $\begin{array}{l}\text { ln(GDP per } \\
\text { capita }\end{array}$ & 0.223 & & & \\
\hline ln(exports) & 0.042 & 0.017 & 2.46 & 0.014 \\
\hline EU membership & 0.039 & 0.062 & 0.62 & 0.534 \\
\hline $\begin{array}{l}\text { Constant } \\
\text { parameters }\end{array}$ & -1.534 & 0.680 & -2.25 & 0.024 \\
\hline $\begin{array}{l}\text { Country: identity } \\
\text { Standard of } \\
\text { coniation }\end{array}$ & 0.083 & Standard error & & \\
\hline
\end{tabular}

Source: author's calculations

Table 3, which presents a linear regression model with mixed-effects, confirms the positive impact of exports and GDP per capita in partner countries of the UK, but membership of the EU for partner countries does not have a significant impact on bilateral FDI. 
Table 3. Mixed-effect linear regression model for explaining bilateral FDI between the United Kingdom and other countries (2001-2017)

\begin{tabular}{|l|l|l|l|l|}
\hline Variable & Coefficient & $\begin{array}{l}\text { Eroarea } \\
\text { standard } \\
\text { robustă }\end{array}$ & $\mathbf{z}$ & $\mathbf{P}>\mathbf{z} \mid$ \\
\hline $\begin{array}{l}\text { ln(GDP per } \\
\text { capita }\end{array}$ & 0.223 & $\mathbf{0 . 0 5 4}$ & $\mathbf{4 . 1 0}$ & $\mathbf{0 . 0 0 0}$ \\
\hline ln(exports) & 0.042 & 0.017 & 2.46 & 0.014 \\
\hline EU membership & 0.039 & 0.062 & 0.62 & 0.534 \\
\hline $\begin{array}{l}\text { Constant effect } \\
\text { Random Estimate } \\
\text { parameters }\end{array}$ & -1.534 & 0.680 & -2.25 & 0.024 \\
\hline $\begin{array}{l}\text { Country: identity } \\
\text { Standard of } \\
\text { deviation } \\
\text { constant }\end{array}$ & 0.083 & 0.030 & & \\
\hline
\end{tabular}

Source: author's calculations

The fixed-effect model in Table 4 confirms the importance of the economic development of the countries investing in the UK or where UK investors decide to make investments. Therefore, it can be considered that there are two major determinants of FDI: GDP per capita, which may suggest also market size, and exports. 
Table 4. Fixed-effect model for explaining bilateral FDI between the UK and other countries (2001-2017)

\begin{tabular}{|l|l|l|l|l|}
\hline Variable & Coefficient & $\begin{array}{l}\text { Robust } \\
\text { standard error }\end{array}$ & $\mathbf{z}$ & $\mathbf{P}>|\mathbf{z}|$ \\
\hline $\begin{array}{l}\ln (\text { GDP per } \\
\text { capita }\end{array}$ & 3.566 & 1.717 & 2.08 & 0.039 \\
\hline $\ln ($ exports) & -1.872 & 0.662 & -2.83 & 0.005 \\
\hline EU membership & 0.786 & 0.676 & 1.16 & 0.246 \\
\hline Constant & 18.897 & 12.282 & 1.54 & 0.125 \\
\hline
\end{tabular}

Source: author's calculations

$90.65 \%$ of the variation in bilateral FDI explained by the fixed-effect model is due to the differences between UK partner countries in terms of GDP per capita, exports and EU membership.

The Poisson mixed-effect model in Table 5, which explains the FDI attracted by the United Kingdom in the period 2001-2017, confirms the importance of the economic development of the countries of origin for the foreign investors that decided to open business in the United Kingdom. The fact that their countries of origin are EU member states or not does not appear to be an important element for foreign investors in the United Kingdom. 
Table 5. Poisson regression model with mixed effects to explain FDI attracted by the United Kingdom (2001-2017)

\begin{tabular}{|c|c|c|c|c|}
\hline Variable & Coefficient & $\begin{array}{l}\text { Robust } \\
\text { standard error }\end{array}$ & $\mathbf{z}$ & $\mathbf{P}>|\mathbf{z}|$ \\
\hline $\begin{array}{ll}\ln (\text { GDP } & \text { per } \\
\text { capita } & \end{array}$ & 0.519 & 0.109 & 4.74 & 0.000 \\
\hline $\ln$ (exports) & 0.070 & 0.030 & 2.29 & 0.022 \\
\hline EU membership & 0.114 & 0.118 & 0.97 & 0.333 \\
\hline Constant & -5.701 & 1.34 & -4.25 & 0.000 \\
\hline $\begin{array}{l}\text { Random effect } \\
\text { parameters }\end{array}$ & Estimate & Standard error & & \\
\hline \multicolumn{5}{|l|}{ Country: identity } \\
\hline $\begin{array}{l}\text { Standard } \\
\text { deviation } \\
\text { constant }\end{array}$ & 0.211 & 0.041 & & \\
\hline
\end{tabular}

Source: author's calculations

The linear regression model on panel data with mixed effects in Table 6 confirms the importance of GDP per capita and exports in attracting FDI by the United Kingdom, giving greater weight to these factors than previous models. 
Table 6. Mixed-effect linear regression model for explaining FDI attracted by the UK (20012017)

\begin{tabular}{|l|l|l|l|l|}
\hline Variable & Coefficient & $\begin{array}{l}\text { Eroarea } \\
\text { standard } \\
\text { robustă }\end{array}$ & $\mathbf{Z}$ & $\mathbf{P}>|\mathbf{z}|$ \\
\hline $\ln$ (PIB pe loc.) & 2.300 & 0.267 & 8.60 & 0.000 \\
\hline $\ln$ (export) & 0.468 & 0.075 & 6.20 & 0.000 \\
\hline membru_ue & 0.358 & 0.294 & 1.22 & 0.224 \\
\hline Constanta & -30.876 & 3.29 & -9.36 & 0.000 \\
\hline $\begin{array}{l}\text { Random effect } \\
\text { parameters }\end{array}$ & Estimate & Standard error & & \\
\hline $\begin{array}{l}\text { țara: identitate } \\
\text { deviația standard } \\
\text { (constanta) }\end{array}$ & 1.975 & 0.085 & & \\
\hline
\end{tabular}

Source: author's calculations

The results obtained are contrary to recent studies. For example, Bruno et al. (2016) achieved an increase in FDI that were attracted by the United Kingdom in the period 1985-2013 from 34 OECD countries by 14\% till 38\% due to the country's EU membership. The opposite result can be explained by the fact that we have selected another time period (2001-2017) and another sample of countries, some of not being members of the EU. We considered in the sample only those countries that attracted significant FDI from the United Kingdom or where British firms achieved significant FDI in that period. Furthermore, the dummy variable reflects the partner country's EU membership and not that of the United Kingdom.

\section{Conclusions}

Many recent empirical papers in international economics has assessed the impact of European economic integration on FDI attracted by the UK, the importance of this assessment increasing in recent years in the context of Brexit. However, the novelty of this research is the evaluation made by comparisons with other countries outside the EU using the difference-indifference estimator. 
Our main results are conditioned by the sample of countries that are the UK's economic partners for FDI. The results are different from the literature. It seems that economic factors are more important than the simple appurtenance to EU. However, our study is limited by the consideration of a small number of variables in the model. In a future research, other aspect related to the economic and social field should be introduced as explanatory variables in the econometric models.

\section{Acknowledgement}

„This work was supported by a grant of Romanian Ministry of Research and Innovation, CNCS UEFISCDI, project number PN-III-P1-1.1-PD-2016-0163, within PNCDI III”.

\section{References}

Alfaro, L., Chanda, A., Kalemli-Ozcan, S., \& Sayek, S. (2004). FDI and economic growth: the role of local financial markets. Journal of International Economics, 64(1), 89-112.

Bailey, D., Driffield, N., \& Karoglou, M. (2017). Brexit means inward investment to the UK will fall. LSE Brexit.

Baker, J., Carreras, O., Ebell, M., Hurst, I., Kirby, S., Meaning, J., ... \& Warren, J. (2016 a). The Short-Term Economic Impact of Leaving the EU. National Institute Economic Review, 236(1), 108-120.

Baker, J., Carreras, O., Kirby, S., Meaning, J., \& Piggott, R. (2016 b). Modelling events: the short-term economic impact of leaving the EU. Economic Modelling, 58, 339-350.

Barrell, R., \& Willem te Velde, D. (2002). European integration and manufactures import demand: an empirical investigation of ten European countries. German Economic Review, 3(3), 263-293.

Barrell, R., FitzGerald, J., \& Riley, R. (2007). EU Enlargement and Migration: Assessing the Macroeconomic Impacts, National Institute for Economic and Social Research Discussion Paper No. 292 (London).

Barrett, A., Bergin, A., FitzGerald, J., Lambert, D., McCoy, D., Morgenroth, E. \& Studnicka, Z. (2015). Scoping the possible economic implications of Brexit on Ireland. ESRI Research Series, 48, 1-85.

Battiston, D., Dickens, R., Manning, A., \& Wadsworth, J. (2014). Immigration and the Access to Social Housing in the UK.

Bellak, C., \& Narula, R. (2008). EU enlargement and consequences for FDI assisted industrial development (No. em-dp2008-69). Henley Business School, Reading University.

Benito, G. R., Grøgaard, B., \& Narula, R. (2003). Environmental influences on MNE subsidiary roles: economic integration and the Nordic countries. Journal of International Business Studies, 34(5), 443-456.

\section{9}


Bergin, A., Conroy, N., Rodriguez, A. G., Holland, D., McInerney, N., Morgenroth, E. L., \& Smith, D. (2017). COSMO: A new COre Structural MOdel for Ireland (No. 553). ESRI Working Paper.

Blackaby, D. (2018). The UK Economy and Brexit. In Emerging Markets from a Multidisciplinary Perspective (pp. 37-45). Springer, Cham.

Campos, N., \& Coricelli, F. (2015). Some unpleasant Brexit econometrics. VoxEU. org.

Capital Economics, C. (2016). The economic impact of 'Brexit'. Report prepared for Woodford Investment Management, Oxford.

Dhingra, S., Ottaviano, G., Rappoport, V., Sampson, T., \& Thomas, C. (2018). UK trade and FDI: A post-Brexit perspective. Papers in Regional Science, 97(1), 9-24.

Ebell, M., \& Warren, J. (2016). The long-term economic impact of leaving the EU. National Institute Economic Review, 236(1), 121-138.

Economists for Brexit. (2016). The Economy After Brexit. http://issuu.com/efbkl/docs/economists_for_brexit_the_economy/1?e=24629146/35248609.

Harvey, D., \& Hubbard, C. (2016). Why Brexit? Centre for Rural Economy Discussion Paper Series, 35, 1-10.

Irwin, G. (2015). BREXIT: the Impact on the UK and the EU. Global Council, London. Disponibil la: https://www.global-counsel.co.uk/sites/default/files/specialreports/downloads/Global\%20Counsel_Impact_of_Brexit.pdf. Accesat la 17.05.2018, ora 10.

Jafari, Y., \& Britz, W. (2017). Brexit-an economy-wide Impact Assessment looking into trade, immigration, and Foreign Direct Investment. In 20th Annual Conference on Global Economic Analysis, June (pp. 7-9).

Kekic, L. (2017). FDI to the UK will remain robust post-Brexit. Disponibil la: https://academiccommons.columbia.edu/catalog/ac:9p8cz8w9hd.

Kierzenkowski, R., Pain, N., Rusticelli, E., \& Zwart, S. (2016). The Economic Consequences of Brexit. OECD Economic Policy Papers, 16, 1-37.

Kilic, C., Bayar, Y., \& Arica, F. (2014). Effects of currency unions on foreign direct investment inflows: the European economic and monetary union case. International Journal of Economics and Financial Issues, 4(1), 8-15.

Economic

Mansfield, I. (2013). A blueprint for Britain: Openness not isolation. Institute for Affairs.http://www.iea.org.uk/sites/default/files/publications/files/Brexit\%20Entry\%20170_final bio_web.pdf.

McGrattan, E. R., \& Waddle, A. (2017). The impact of Brexit on foreign investment and production (No. w23217). National Bureau of Economic Research.

Pain, N. (1997). Continental drift: European integration and the location of UK foreign direct investment. The Manchester School, 65(S), 94-117.

Pain, N., \& Lansbury, M. (1997). Regional economic integration and foreign direct investment: the case of German investment in Europe. National Institute Economic Review, 160(1), 87-99.

Pain, N., \& Young, G. (2004). The macroeconomic impact of UK withdrawal from the EU. Economic Modeling, 21(3), 387-408.

\section{0}


PWC (2016). Leaving the EU: Implications for the UK Economy. Disponibil la: http://www.pwc.co.uk/economic-services/assets/leaving-the-eu-implications-for-the ukeconomy.pdf. Accesat la 23.05.2018, ora 11.

PWC (2016). Leaving the EU: Implications for the UK Economy. Disponibil la: http://www.pwc.co.uk/economic-services/assets/leaving-the-eu-implications-for-the ukeconomy.pdf.

Rădulescu, M., \& Jianu, E. (2011). FDIs in Spain after its EU accession. Spanish investments in Romania and how can be used Spanish experience for Romania's development. Annals of the University of Petrosani Economics, 11(2), 233-256.

Simionescu, M. (2017). The Influence of Brexit on the Foreign Direct Investment Projects and Inflows in the United Kingdom (No. 68). GLO Discussion Paper.

Straathof, B., Linders, G. J., Lejour, A., \& Jan, M. Ã. (2008). The internal market and the Dutch economy: Implications for trade and economic growth (No. 168). CPB Netherlands Bureau for Economic Policy Analysis.

Wordin, A. (2018). Ireland and the Economic Impacts of Brexit. Pepperdine Policy Review, 10(1), 3. 